\title{
DIFFUSE LIPOMATOSIS OF THYROID GLAND MASQUERADING AS MALIGNANCY: A CASE REPORT
}

\author{
Amandeep Sing Nar ${ }^{1}$, Ashvind Bawa², Atul Mishra ${ }^{3}$, Ashwani Kumar ${ }^{4}$, Rajesh Kumar Jassal ${ }^{5}$ \\ ${ }^{1}$ Assistant Professor, Department of Surgery, Dayanand Medical College \& Hospital, Ludhiana. \\ ${ }^{2}$ Assistant Professor, Department of Surgery, Dayanand Medical College \& Hospital, Ludhiana. \\ 3 Professor, Department of Surgery, Dayanand Medical College \& Hospital, Ludhiana. \\ 4 Professor, Department of Surgery, Government Medical College \& Hospital, Patiala. \\ 5 Senior Resident, Department of Surgery, Dayanand Medical College \& Hospital, Ludhiana.
}

\section{ABSTRACT}

Infiltration of the thyroid gland by adipose tissue is a very rare phenomenon. It is generally seen as a separate entity with diffuse presence of mature fat cells called Diffuse Lipomatosis of thyroid. We are presenting a case of 52-year-old male having thyroid swelling, which was causing respiratory obstructive symptoms and hoarseness of voice, mimicking malignancy. Patient was taken up for Total Thyroidectomy. Intraoperatively, lipomatous tumour-like tissue was found replacing the thyroid gland. Histopathological examination of the specimen showed abundant mature fat cells with thyroid follicles and also scanty amount of amyloid material.

\section{KEYWORDS}

Thyroid Gland, Lipomatosis, Diagnosis.

HOW TO CITE THIS ARTICLE: Nar AS, Bawa A, Mishra A, et al. Diffuse lipomatosis of thyroid gland masquerading as malignancy: a case report. J. Evolution Med Dent Sci. 2016;5(60):4239-4240, DOI: 10.14260/jemds/2016/966

\section{INTRODUCTION}

Infiltration of thyroid gland by fatty tissue is a rare entity.(1) and can be associated with a spectrum of conditions viz. Diffuse Lipomatosis of thyroid gland. ${ }^{2}$, Adenolipoma, Amyloid Goitre, Intrathymic or Parathyroid Lipoma, Lipid Rich Clear Cell Adenoma, Lymphocytic Thyroiditis and Malignant tumours like Liposarcoma, Encapsulated Papillary Carcinoma of thyroid. Except for diffuse lipomatosis, all other conditions are mostly localised or variable fatty infiltrations of the thyroid.(1,3,4) We present you a rare case of thyroid pathology, initially thought to be carcinoma because of features of respiratory distress and voice change, but histopathology examination revealed it to be a diffuse lipomatosis of thyroid gland.

\section{CASE REPORT}

A 52-year-old male presented with chief complaints of swelling in neck for 2 years, respiratory obstructive features for 3 months and hoarseness of voice for last 1 week. Haemogram, renal function tests and thyroid function tests were within normal range. Previous FNAC from the swelling showed Hurthle cells and follicular epithelial cells. MRI neck showed diffuse infiltrative lesion $107 \times 85 \times 52 \mathrm{~mm}$ compressing false vocal cords, supraglottic laryngeal portion and minimal compression of the trachea with posterolateral displacement of the b/l carotid vessels. Patient was suspected to have carcinoma on clinical basis with infiltrative lesion seen on MRI and hence total thyroidectomy was planned. Intraoperatively,

Financial or Other, Competing Interest: None.

Submission 04-02-2016, Peer Review 09-03-2016,

Acceptance 14-03-2016, Published 28-07-2016.

Corresponding Author:

Dr. Ashvind Bawa,

Bawa Hospital,

Near Old Dandi Swami Mandir,

Civil Lines,

Ludhiana

E-mail: drbawa@gmail.com

DOI: $10.14260 /$ jemds $/ 2016 / 966$ lipomatous tumour-like material was observed replacing the thyroid gland tissue. Sections of histopathological examination showed thyroid follicles separated by mature adipose tissue in majority of the area and focal amyloid deposition. Postoperatively, patient responded well with relief of the respiratory obstructive features and the improvement in voice.

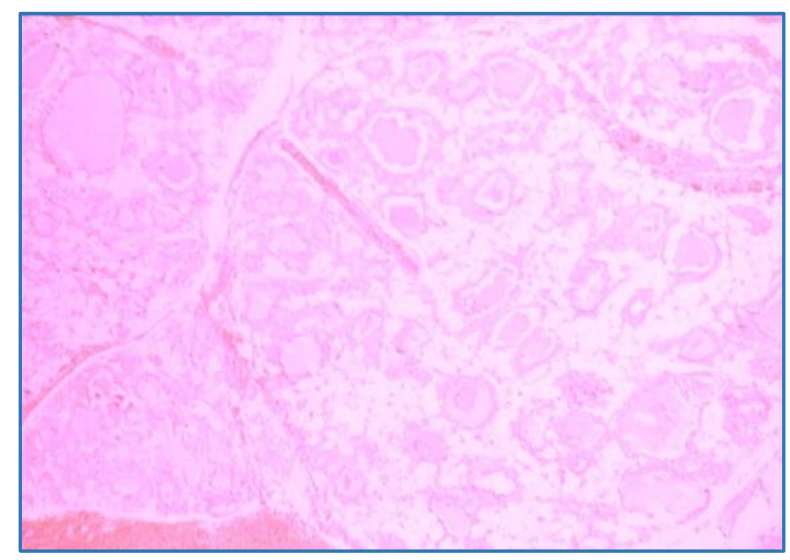

Fig. 1: Slide Showing Thyroid Follicles Separated by Adipose Cells in Majority of the Areas

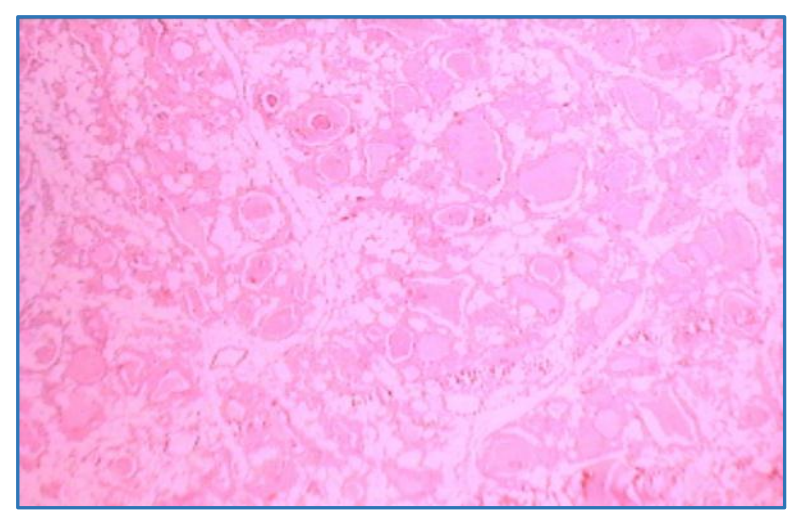

Fig. 2: Slide Showing Separation of Thyroid Follicles by Fat Cells as well as Focal Amyloid Deposition Intermittently 


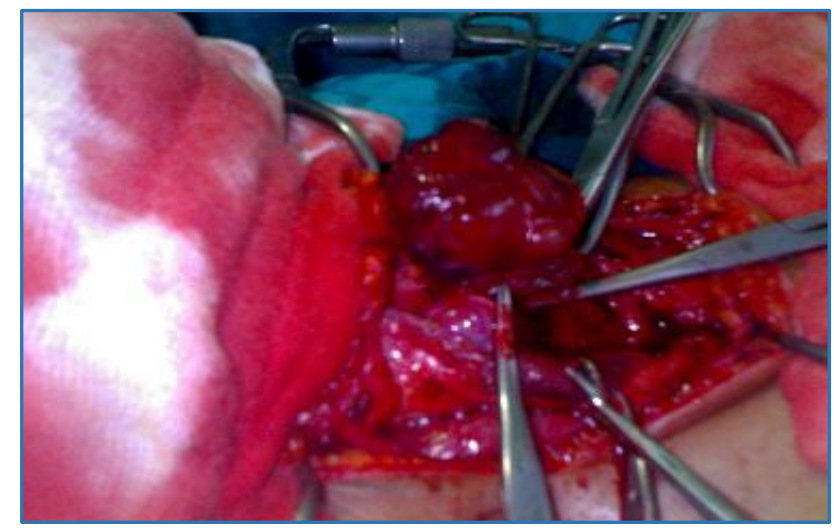

Fig. 3: Intraoperative Picture Showing Whitish Multiple Nodular Appearance to the Thyroid Gland

\section{DISCUSSION}

In normal thyroid gland very few adipocytes can be found in perivascular region at the capsule.(5) Significant fatty tissue in thyroid tissue is a rare occurrence. Various conditions which will show adipose tissue in thyroid include heterotopic nests of adipocytes, diffuse lipomatosis, adenolipoma, amyloid goitre, encapsulated papillary carcinoma, liposarcoma and lymphocytic thyroiditis.(1)

Origin of adipose tissue in thyroid is unclear and various theories have been given to explain it. Some consider it a developmental anomaly, because of entrapment of fat cells before the development of the capsule of thyroid explaining the heterotopic nests of fat in thyroid. $(5,6,7)$ Some consider it to be metaplastic change of fibroblasts because of chronic hypoxia. $(8,9)$

Diffuse fatty infiltration of the thyroid tissue on gross inspection is called diffuse lipomatosis of thyroid.(7) Lipomatosis may manifest as congenital swelling.(3) Aspiration cytology would reveal mixture of adipocytes and follicular cells of thyroid and thus can lead to preoperative diagnosis.(6)

Amyloid deposition has also been seen in adipose tissue in cases of diffuse lipomatosis of thyroid.(2)

Imaging modalities for diagnosing fatty tissue include CT and MRI of the neck. CT neck shows the fat as nonhomogeneous tissue with low attenuation value consistent with fat. MR imaging of the neck with fatty tissue reveals large irregular areas of $\mathrm{T} 1$ weighted hyperintensity that become hypointense on fat suppressed transverse spectral presaturation inversion recovery T1 weighted MR image.(1)

Although, gross fatty tissue in thyroid gland is very rare incidence, but if it is seen then whole spectrum of various conditions remains as open possibility. It can show up as only focal presence to gross infiltration replacing almost whole of the thyroid gland by adipose tissue. They can also present variably in clinical settings as seen in our case with gradually increasing painless thyroid swelling associated with respiratory obstructive symptoms and voice change, thus mimicking malignancy. But final diagnosis could be arrived on as diffuse lipomatosis only on histopathological examination.

\section{REFERENCES}

1. Borges A, Catarino A. Case 53: Adenolipoma of the thyroid gland. Radiology 2002;225:746-50.

2. Dhayagude RG. Massive fatty infiltration in a colloid goiter. Arch Pathol 1942;33:357-360.

3. Chesky VE, Dreese WC, Hellwig CA. Adenolipomatosis of the thyroid. Surgery 1953;34(1):38-45.

4. Dombale VD, Javalgi AP, Kalburgi. Symmetric diffuse lipomatosis of the thyroid gland. JCDR 2011;5(4): 867- 68.

5. Kitagawa W, Kameyama K, Tamai S, et al. Adenolipoma of the thyroid gland: report of a case. Surg Today 2004;34(7):593-6.

6. Schroder S, Bocker W. Lipomatous lesions of the thyroid gland: a review. Appl Pathol 1985;3(3):140-9.

7. Arslan A, Alic B, Uzunlar AK, et al. Diffuse lipomatosis of the thyroid gland. Auris Nasus Larynx 1999;26(2):213-5.

8. Gnepp DR, Ogorzalek JM, Heffess CS. Fat-containing lesions of the thyroid gland. Am J Surg Pathol 1989;13(7):605-12.

9. Laforga J, Vierna J. Adenoma of the thyroid gland containing fat (thyrolipoma): report of a case. J Laryngol Otol 1996;110(11):1088-9. 